\title{
HAK DAN KEWAJIBAN JANDA CERAI MATI DALAM HUKUM ADAT LAMPUNG PEPADUN LAMPUNG TENGAH PERSPEKTIF GENDER ${ }^{1}$
}

\author{
Qosim Khoiri Anwar ${ }^{1}$, Habib Shulton Asnawi ${ }^{2}$, Annikmah Farida ${ }^{3}$ \\ ${ }^{1}$ Universitas Islam Negeri Maulana Malik Ibrahim, Jawa Timur \\ ${ }^{2}$ Institut Agama Islam Maarif NU, Metro Lampung \\ ${ }^{3}$ Institut Agama Islam Maarif NU, Metro Lampung \\ *CORRESPONDENCE $\square$ habibshulton1708@gmail.com
}

\begin{abstract}
This research examines the facts of injustice against the divorcee died in the customary Article History

law of Lampung Lampung Pepadun Marga Anak Represents the Middle Lampung. The Received: 29-12-2018

be born is backed by the social perception of perception in the form of the myths of superiority a man trusted by the community. This research method is the type of field research, which are sociological qualitative analysis method with ethnographic. The primary data source is the custom of Lampung Pepadun, religious figures, as well as widows divorcees to death. The purpose of this research is to know the rights and obligations of the divorcee died in the customary law of Lampung Lampung Pepadun Marga Anak Represents the Middle Lampung in the perspective of Gender. Research results themselves that the provisions of the law on the rights and obligations of the divorcee died in the customary law of Lampung Lampung Pepadun Marga Anak Represents the middle of conflicting and inconsistent with the principles of fairness and gender equality.
\end{abstract}

Article Info

fact of the injustice done to the women starting from the existence of a pattern of Revised : 30-12-2018

relations of power that lame between men with women. Justification authorities it can Accepted:31-12-2018

Keywords:

The Rights and Obligations of the Divorcee Died; Lampung Pepadun; Gender Justice;

\begin{abstract}
Abstrak
Penelitian ini mengkaji fakta ketidakadilan terhadap janda cerai mati dalam hukum adat Histori Artikel Lampung Pepadun Marga Anak Tuha Lampung Tengah. Fakta ketidakadilan terhadap Diterima: 29-12-2018 kaum perempuan tersebut bermula dari adanya pola relasi kekuasaan yang timpang Direvisi: 30-12-2018 antara laki-laki dengan perempuan. Justifikasi atas otoritas itu bisa lahir didukung oleh Disetujui: 31-12-2018 persepsi-persepsi social dalam bentuk mitos-mitos superioritas seorang laki-laki yang dipercayai oleh masyarakat. Jenis metode penelitian ini adalah penelitian lapangan, yang bersifat sosiologis etnografis dengan metode analisis kualitatif. Sumber data primernya adalah tokoh adat Lampung Pepadun, tokoh agama, serta janda-janda cerai mati. Tujuan penelitian ini adalah untuk mengetahui hak dan kewajiban janda cerai mati dalam hukum adat Lampung Pepadun Marga Anak Tuha Lampung Tengah dalam Kata Kunci: Perspektif Gender. Hasil penelitian pembuktikan bahwa ketentuan hukum tentang hak Hak dan Kewajiban Janda dan kewajiban janda cerai mati dalam hukum adat Lampung Pepadun Marga Anak Tuha Cerai Mati; Lampung Tengah bertentangan serta tidak sejalan dengan prinsip-prinsip keadilan dan Lampung Pepadun; kesetaraan gender.

Keadilan Gender;
\end{abstract}

\section{A. Pendahuluan}

Islam secara normati dengan tegas mengakui konsep keadilan dan kesetaraan antara laki-laki dan perempuan[1]. Keadilan dan kesetaraan gender berlandaskan pada prinsip-prinsip yang memposisikan laki-laki dan perempuan yang sama sebagai hamba Tuhan. Keadilan dan kesetaraan gender dalam Islam secara substansi mengandung dua makna: Pertama pengakuan secara umum atas kesetaraan antara laki-laki dan perempuan, tanpa membedakan jenis kelamin. Kedua, mengakuan atas kesejajaran hak dan keawajiban antara laki-laki dan perempuan dalam berbagai bidang[2]. Dalam konteks yuridis upaya perlindungan terhadap hak-hak kaum perempuan, dunia

\footnotetext{
${ }^{1}$ Artikel ini adalah hasil penelitian kelompok yang didanai oleh DIPA Kementerian Agama RI Tahun 2016. P-ISSN: 2527- 4430 E-ISSN: 2548-7620
}

Copyright (C) 2018 Fikri: Jurnal Kajian Agama, Sosial dan Budaya 
internasional juga telah merumuskan Konvensi Penghapusan Segala Bentuk Diskriminasi terhadap Perempuan atau disebut Convention on the Elimination All Form of Discrimination Against Women $(C E D A W)$. Indonesia telah meratifikasi Konvensi Mengenai Penghapusan Segala Bentuk Diskriminasi terhadap Perempuan melalui UU. No. 7 Tahun 1984. Konsekuwensi dari ratifikasi Konvensi CEDAW tersebut adalah negara (peratifikasi) wajib melaksanakan asas-asas yang tercantum dalam Konvensi tersebut secara komitmen, melalui undang-undang, kebijakan atau program-program sebagai upaya melindungi, menegakkan keadilan, kesetaraan serta terhapusnya segala bentuk diskriminasi terhadap perempuan. Termasuk merubah praktek-praktek kebiasaan dan budaya yang didasarkan pada inferioritas atau superioritas salah satu jenis kelamin atau peran stereotipe untuk perempuan dan laki-laki.

Namun faktanya status dan peran perempuan diberbagai masyarakat hingga sekarang ini pada umumnya masih berada pada posisi yang penuh dengan ketidakadilan dan diskriminasi[3]. Khususnya dalam penelitian ini adalah dalam konteks hak dan kewajiban yang dialami oleh janda cerai mati dalam hukum adat Lampung Pepadun khususnya Marga Anak Tuha Kabupaten Lampung Tengah[4].

Dalam konteks hak, pertama hak terhadap harta waris. Di dalam ketentuan hukum Adat Lampung Pepadun Marga Anak Tuha, perempuan atau istri tidak mendapatkan bagian harta waris dari almarhum suaminya, ketika suami meninggal dunia ketentuan di dalam hukum adat Lampung Pepadun harta kembali dan dikelola oleh keluarga almarhum suaminya. Dalam konteks kewajiban, pertama, setelah suami meninggal, seorang janda cerai mati tidak diizinkan untuk kembali kerumah orang tuanya (menetap). Kedua, jika janda cerai mati ingin menikah kembali diharuskan untuk menikah dengan kerabat dari pihak almarhum suami. Ketiga, seandainya si janda tetap melakukan pernikahan dengan laki-laki yang bukan berasal dari kerabat almarhum suami maka mereka (janda dan calon suami) diwajibkan untuk melakukan upacara adat terlebih dahulu. Jika syarat dan upacara adat tersebut tidak dilaksanakan maka secara adat janda tersebut dianggap telah mati, dan ada konsekuwensi yang akan ditanggung oleh janda cerai mati tersebut. Karena si janda dianggap telah mati, maka hal ini berpengaruh bagi janda cerai mati yang ingin menikah kembali karena berkaitan erat dengan hak-hak yang seharusnya diterima oleh sijanda seperti hak waris, hak pemeliharan anak dan hak-hak yang lainnya[5].

Fakta ketidakadilan terhadap kaum perempuan masyarakat adat Lampung Pepadun Marga Anak Tuha tersebut di atas, bermula dari adanya pola relasi kekuasaan yang timpang antara lakilaki dengan perempuan. Justifikasi atas otoritas itu bisa lahir didukung oleh persepsi-persepsi social dalam bentuk mitos-mitos superioritas seorang laki-laki yang dipercayai oleh masyarakat tertentu. Dengan menggunakan alur pikir semacam ini, maka ketidakadilan yang terjadi merupaka jenis ketidakadilan yang berbasis "Gender". Ketimpangan itu lahir disebabkan oleh perbedaan peranperan gender yang dikonstruksi secara social dimana salah satu pihak menjadi subordinat dari pihak lain[6]. Anggapan bahwa perempuan lebih rendah dari pada laki-laki memunculkan doktrin ketidak-adilan serta ketidak-setaraan antara laki-laki dan perempuan yang kemudian melahirkan nilai-nilai patiarkhi. Konstruk budaya patiarkhi yang mapan secara universal dan berlangsung selama berabad-abad hal tidak lagi dipandang sebagai ketimpangan, bahkan ini diklaim sebagai "fakta ilmiah"

Ada beberapa hasil penelitian yang mengkaji tentang sistem hukum adat, diantaranya adalah: (1) Penelitian yang dilakukan oleh Annisa Tunjung Sari,SH dengan judul "Kedudukan Anak LakiLaki Tertua dari Hasil Perkawinan Leviraat dalam Hukum Waris Adat Masyarakat Lampung 
Pepadun (Studi Kasus di Kampung Terbanggi Besar Kecamatan Terbanggi Besar Lampung Pemerintahan Kabupaten Lampung Tengah)'. Di dalam ini menyimpulkan bahwa bentuk perkawinan pada masyarakat adat Lampung Pepadun menganut perkawinan dengan pembayaran uang jujur. Mengenai perkawinan dalam masyarakat Lampung mempunyai prinsip pantang untuk bercerai. Dimana setelah isteri berada di tempat suami, ia termasuk dalam kerabat suami yang menjadi tanggungjawab suami dan kerabat suami. Jika suami meninggal, isteri tetap berada dirumah suami. Bahkan menurut hukum adat ia harus kawin dengan saudara suami (Semalang/Leviraat). (2). Penelitian yang ditulis oleh H. Imran, S.Ag. SH. MH dengan judul “Kedudukan Janda Menurut Hukum Waris Adat dan Waris Islam”. Penelitian ini menjelaskan bahwa kedudukan janda dalam hukum waris adat secara umum tidak termasuk dalam kelompok ahli waris dan tidak pula mendapat harta warisan dari harta peninggalan suaminya. Janda hanya dapat menikmati harta peninggalan almarhum suaminya sebagai jaminan nafkah hidup. Sedangkan kedudukan janda dalam hukum waris Islam sama dengan kedudukan ahli waris lainnya seperti kedudukan suami, ayah, ibu, anak laki-laki dan anak perempuan tidak pernah mahjub hirman/terhalang. Dan mendapat bagian seperempat bila tidak ada anak dan seperdelapan bila ada anak. (3). Penelitian yang ditulis oleh Villa Sari dengan judul "Kedudukan Janda dalam Hukum Adat yang Berlaku di Semarang”, dalam thsesis ini dijelaskan bahwa kedudukan seorang janda menurut hukum adat yang berlaku di Kabupaten Semarang adalah bukan sebagai ahli waris dari suaminya yang telah meninggal dunia. Oleh karena itu seorang janda tidak berhak atas harta asal dari suaminya tetapi ia berhak atas sebagian dari harta gono gini untuk memenuhi kebutuhan hidupnya asalkan ia tidak kawin lagi. Apabila ia kawin lagi maka harta asal suami akan kembali kepada ahli waris almarhum suaminya dan ia berhak atas sebagian harta gono gini.

Dari beberapa penelitian di atas peneliti tidak menemukan bahasan tentang hak dan kewajiban janda cerai mati masyarakat adat Lampung Pepadun Perspektif Gender. Dengan demikian dari penelitian-penelitian terdahulu sejauh pengamatan dan pengetahuan peneliti, masalah yang akan peneliti teliti dalam penelitian ini adalah penelitian baru yang belum pernah dilakukan sebelumnya. Oleh karena itu penelitian tentang hak dan kewajiban janda cerai mati dalam adat Lampung Pepadun Perspektif Gender (Studi di Marga Anak Tuha Lampung Tengah) menarik untuk dibahas secara mendalam.

Tujuan atau rumusan masalah yang akan dikaji dalam penelitian ini adalah bagaimanakah hak dan kewajiban janda cerai mati dalam hukum adat Lampung Pepadun Perspektif Gender (Studi di Marga Anak Tuha Lampung Tengah)?.

\section{B. Metode Penelitian}

Jenis penelitian ini adalah penelitian lapangan ( Field risearch), paper atau artikel ini adalah hasil penelitian yang dilakukan di Daerah Lampung khususnya masyarakat Lampung Pepadun Marga Anak Tuha Labupaten Lampung Tengah Provinsi Lampung. Penelitian ini bersifat sosiologis ethnografis dengan metode analisis kualitatif. Sumber data primer dalam penelitian ini adalah semua informasi yang diperoleh dari masyarakat adat Lampung Pepadun. Informasi ini diperoleh dari beberapa Janda cerai, Keluarga almarhum suami dari janda cerai, Tokoh Agama Di Wilayah Marga Anak Tuha 1 Orang, Tokoh adat Lampung Pepadun Marga Anak Tuh, Kepala di Kecamatan Anak Tuha dan Padang Ratu Kabupaten Lampung Tengah. Tehnik pengumpulan data penelitian ini adalah observasi, wawancara dan dokumentasi. Di dalam menganalisis data penelitian menggunakan metode berfikir induktif. Yang dimakhsud metode induktif adalah berangkat dari faktor-faktor dan peristiwa yang konkrit. Kemudian dari faktor-faktor dan peristiwa yang konkrit itu 
ditarik generalisasi yang bersifat umum. Metode induktif digunakan antara lain dengan bertolak dari sejumlah peristiwa adat tentang hak-hak janda karena cerai mati di masyrakat Lampung Pepadun yang diteliti, lalu ditarik kesimpulan yang bersifat umum, artinya apakah hak-hak janda karena cerai mati di masyarakat lampung Pepadun Marga Anak Tuha sudah sesuai dengan prinsip-prinsip keadilan Gender.

\section{Pembahasan}

\section{Gambaran Umum Masyarakat Adat Lampung Pepadun Marga Anak Tuha}

Marga Anak Tuha merupakan sekelompok masyarakat adat yang berada diwilayah Kecamatan Anak Tuha dan Kecamatan Padang Ratu. Marga Anak Tuha terdiri 2 kebuaian yaitu Kebuaian Riau dan Kebuaian Ajai. 2 kebuaian ini terdiri dari 11 kampung, 8 kampung dari kecamatan Anak Tuha dan 3 kampung dari Kecamatan Padang Ratu. Dalam struktur lembaga adat Marga Anak Tuha kedudukan tertinggi berada di tangan tokoh adat. Karena Marga Anak Tuha ini merupakan kelompok masyarakat adat dari 11 kampung, maka tokoh adat dari 11 kampung yang tergabung mewakili setiap kampungnya untuk menjadi tokoh adat di Marga Anak Tuha. Begitu pula untuk penyeimbang adat dari 11 kampung yang tergabung dalam Marga Anak Tuha juga menjadi penyeimbang adat di Marga Anak Tuha[5].

Struktur masyarakat adat ini pada hakekatnya menunjukkan tingkat kewenangan seseorang dalam keluarga, kerabat dan masyarakat adat, baik dalam suatu kebuayan, kelompok dan masyarakat adat lainnya. Lembaga adat ini memperhatikan prinsip kebersamaan dalam kehidupan bermusyawarah dalam mendapatkan kata mufakat yang kemudian menjadikannya keputusan yang harus ditaati oleh seluruh warga masyarakatnya. Segala sesuatu keputusan berupa ketetapan ini harus dilakukan dalam suatu rapat yang disebut perwatin adat (musyawarah para punyimbang dan tokoh adat) sesuai dengan tingkatannya. Penyimbang dan tokoh adat memiliki kewenangan yang cukup luas mengatur kehidupan dan kehidupan anggota masyarakat baik yang berkenaan dengan hubungan sesama anggota masyarakat maupun yang berkenaan dengan lingkungan alam sekitarnya[5].

Dalam sidang perwatin tidak ada pemisahan antara tokoh adat denga penyimbang adat didalam pengambilan kebijakan. Setiap penyimbang adat atau tokoh adat mempunyai hak yang sama untuk berbicara, berinisiatif, memecahkan masalah, memutuskan atau menetapkan akibat hukum atas persoalan yang dihadapi[5]. Secara sistematis tanggung jawab penyimbang adat dilaksanakan secara berjenjang yaitu masalah yang menyangkut suku diselesaikan oleh para penyimbang suku, dilaporkan kepada penyimbang kampung atau buwai yang ada di kampung yang bersangkutan. Gambaran ini menunjukkan bahwa tingkatan musyawarah itu dimulai dari musyawarah keluarga, musyawarah suku dan musyawarah kampung (marga). Dalam masyarakat adat Lampung Pepadun Marga Anak Tuha bagi para tokoh adat dan para penyeimbag adat tidak ada pembagian kerja secara jelas hanya berdasarkan keahlian masing-masing tokoh adat dan penyeimbang adat[5].

\section{Ketentuan Hak dan Kewajiban Janda Cerai Mati dalam Hukum Adat Lampung Pepadun}

Apabila terjadi putus perkawianan baik karena kematian ataupun karena perceraian dalam masyarakat hukum adat tentunya dilihat suami istri dan keluarga yang bersangkutan apakah mereka berada didalam ruang lingkup masyarakat adat yang menganut sistem matrileneal, patrileneal atau parental, bagaimana bentuk perkawinan yang mereka lakukan dan situasi lingkungan yang mempengaruhi apakah mereka bertempat dikediaman didaerah yang bersangkutan apakah di desa, dikota ataukah di perantauan. Akibat hukum yang timbul dari sistem patrilinial yang dianut oleh ma syarakat adat Lampung Pepadun adalah, bahwa isteri karena perkawinannya (perkawinan dengan 
sistem pembayaran uang jujur) dikeluarkan dari adat orang tua kandungnya kemudian masuk adat suaminya. Anak-anak yang lahir mengikuti adat bapak (suami), harta yang ada milik bapak (suami) nantinya diperuntukkan bagi anak-anak keturunannya.

Berdasarkan hasil penelitian penulis, apabila suami meninggal dunia maka istri mempunyai hak dan kewajiban yang harus ditunaikan. Adapun hak dan kewajiban tersebut adalah: (a) Hak Iddah. Dalam adat Lampung Pepadun seorang istri yang ditinggal mati oleh suaminya harus melaksanakan masa iddah (berkabung). Karena sistem perkawinan masyarakat adat lampung menggunakan hukum Islam dan hukum perkawinan yang berlaku di indonesia maka masa iddah yang berlaku dimasyarakat adat Lampung Pepadun adalah 4 bulan 10 hari jika janda tersebut tidak sedang hamil akan tetapi apabila janda tersebut sedang hamil maka iddahnya adalah sampai melahirkan. Selama masa iddah seorang janda cerai mati harus tinggal dirumah suami apabila selama dalam perkawinan mereka sudah memiliki tempat tinggal. Akan tetapi apabila selama dalam perkawinan mereka belum memiliki tempat tinggal maka janda cerai mati wajib tinggal dirumah orang tua almarhum suami. Dalam masa iddah seorang janda cerai mati tidak diperbolehkan menetap (tinggal) kembali kerumah orang tua kandungnya karena secara adat dia sudah terlepas dari adat orang tua kandungnya. Akan tetapi kalau hanya berkunjung atau menginap beberapa hari dirumah orang tuanya untuk silaturahmi atau mengunjungi orang tuanya diperbolehkaan selama dia tidak berniat untuk menetap kembali[7]. Janda cerai mati ketika dalam masa iddah tetap diperbolehkan bekerja sebagaimana dia bekerja ketika almarhum suaminya masih hidup[7]. (b) Hak Nafkah. Selama masa iddah dan selama belum bersuami, seorang janda cerai mati dan anak-anak dari hasil perkawinan mereka mendapat nafkah dari penghasilan harta peninggalan suami jika ada, tetapi apabila tidak ada penghasilan dari peninggalan harta suami maka nafkah istri dan anakanaknya menjadi tanggungan saudara laki-laki almarhum suami terutama anak laki-laki tertua dan orang tua suami (kerabat). Akan tetapi sebenarnya dalam adat Lampung Pepadun nafkah yang menjadi beban saudara suami (keluarga suami) adalah anak-anak dari hasil perkawinan mereka jadi bukan semata-mata istri yang ditinggal mati oleh suaminya, tetapi ketika saudara suami yang meninggal (orang tua suami yang meninggal) memberikan nafkah kepada anak-anak dari hasil perkawinan mereka secara otomatis janda tersebut juga mendapat nafkah dari saudara suami (orang tua). Akan tetapi apabila janda cerai mati tersebut tidak mempunyai anak dari hasil perkawinan mereka maka nafkah selama masa iddah dan selama belum bersuami tetap menjadi tanggungan saudara laki-laki, orang tua atau kerabat almarhum suami[7]. (c) Hak Waris. Di masyarakat adat Lampung Pepadun dalam sebuah perkawinan tidak ada pemisahan antara harta suami dengan harta istri juga tidak dikenal istilah harta bersama. Semua harta yang didapat selama perkawinan termasuk harta atau barang istri yang diperoleh dari pemberian orang tua atau kerabatnya dan harta suami yang diperoleh dari orang tuanya semua dijadikan satu tanpa ada pemisahan. Kecuali mahar dalam perkawinan merupakan hak milik pribadi istri[7].

Oleh karena itu seorang janda yang ditinggal mati oleh suaminya tidak mendapat bagian harta warisan karena istri bukan merupakan ahli waris dari suaminya. Harta peninggalan almarhum suami diwariskan kepada anak-anak (anak laki-laki tertua) dari hasil perkawinan mereka. Tetapi jika anakanak masih kecil-kecil atau masih belum dewasa dan belum mampu mengurus harta warisannya maka yang mengurus harta warisan mereka adalah ibunya sampai mereka dewasa. Apabila suami yang meninggal itu merupakan anak laki-laki tertua dalam keluarganya maka harta peninggalan dari almarhum suami secara otomatis nantinya juga akan dipergunakan untuk membianyai kelangsungan kehidupan adik-adik dan keluarga yang menjadi tanggungan almarhum suaminya selama masa 
hidupnya.[8]Janda cerai mati hanya boleh memanfaatkan (menikmati) harta peninggalan suami tetapi tidak berhak untuk menjualnya untuk kepentingannya sendiri. Akan tetapi apabila ada anak dari hasil perkawinan mereka isrtri boleh menjual harta peninggalan suami selama itu dipergunakan untuk kepentingan anak-anaknya misalnya untuk biaya pendidikan anak-anak[5]. (d) Hak Hadhanah (Memelihara anak). Dalam masyarakat adat Lampung Pepadun seorang janda cerai mati ia dapat memilih menikah dengan saudara suami atau menikah dengan lelaki lain yang disukainya tetapi suaminya yang baru harus menggantikan kedudukan almarhum suaminya dan masuk dalam kerabat almarhum suaminya, dan tetap memelihara dan mengurus anak-anak, atau ia tetap menjanda dengan mengurus atau memelihara serta mendidik anak-anaknya dengan menggunakan harta peninggalan suami dibawah perlindungan dan bantuan saudara-saudara suaminya.

Selain hak, apabila suami meninggal dunia maka istri kewajiban yang harus ditunaikan, adapun kewajiban tersebut adalah: (a) Janda diwajibkan menjalankan (perkawinan Leviraat /Nyemalang). Seorang janda cerai mati dalam adat Lampug Pepadun jika ingin menikah kembali diharapkan akan menikah dengan saudara (kerabat) dari pihak almarhum suami (perkawinan Leviraat /Nyemalang). Akan tetapi jika janda tersebut tidak mau menikah dengan saudara (kerabat) almarhum suami maka ada syarat adat yang harus dipenuhi terlebih dahulu (menyatukan darah) sehingga calon suami tersebut bisa mengantikan posisi almarhum suami baik sebagai anak laki-laki dari orang tuanya, kepala rumah tangga ataupun kedudukan almarhum diadat, yaitu calon suaminya harus diangkat menjadi anak terlebih dahulu secara adat oleh orang tua almarhum suami. Dengan diangkatnya calon suami tersebut maka secara adat calon suami itu sudah menggantikan kedudukan almarhum suami baik secara adat maupun secara tanggungjawab sebagai kepala keluarga[9].

Syarat adat ini kelihatannya mudah untuk dilaksanakan, akan tetapi sebenarnya tidak mudah untuk dilaksanakan karena dalam proses adat ini ada beberapa syarat yang harus dipenuhi oleh calon suami janda cerai mati tersebut. Syarat-syarat tersebut adalah:[5] (1) Calon suami harus mau masuk menjadi bagian dari adat istri (janda cerai mati) serta mau dan rela meninggalkan kelompok adat orang tua kandungnya. Syarat ini berlaku untuk calon suami yang sama-sama berasal dari suku Lampung. Syarat ini cukup berat dilaksanakan oleh calon suami yang sama-sama berasal dari suku Lampung karena dengan masuknya dia ke kelompok adat istri secara tidak langsung ia telah membuang diri dari adat orang tua kandungnya sendiri. Hal ini yang sering menjadi pertimbangan bagi para lelaki yang ingin menikahi janda cerai mati dari masyarakat Lampung Pepadun karena dengan menikahi janda cerai mati dia tidak bisa membawa janda tersebut masuk menjadi bagian dari kelompok adatnya tetapi justru dialah yang harus membuang diri dari adat orang tua kandungnya dan masuk ke kelompok adat calon istrinya. Dengan membuang dirinya secara adat maka dia akan mendapat malu karena hal ini sangat berkaitan erat dengan pandangan hidup yang dipegang oleh masyarakat adat Lampung yaitu "Pi-ill Pesenggiri". Dengan membuang diri dari adat orang tua kandungnya maka dia juga tidak akan mendapatkan hak-haknya sebagai anak lakilaki dalam sebuah keluarga seperti hak waris, hak menggantikan kedudukan orang tua secara adat dan lain sebagainya. (2) Calon suami harus mau menggantikan kedudukan almarhum suami baik itu secara adat maupun sebagai kepala rumah tangga. Syarat ini juga termasuk syarat yang berat yang harus dilaksanakan oleh calon suami karena dia harus menggantikan kedudukan almarhum suami secara adat dengan segala konsekuensinya dan harus sanggup menggantikan kedudukan almarhum suami sebagai kepala rumah tangga dan apabila almarhum suami adalah anak laki-laki tertua dalam keluarganya maka secara otomatis tanggung jawab terhadap kelangsungan hidup orang tua dan adik-adik almarhum suami juga harus sanggup dipikul oleh calon suami tersebut. Jika syarat ini 
tidak sanggup diterima oleh calon suami maka pernikahan tersebut bisa digagalkan oleh adat. (3) Menetap. Setelah menikah dengan janda tersebut harus mau tinggal dan menetap dikampung dimana istri tinggal bersama dengan almarhum suami sebelumnya. Calon suami dan janda tersebut boleh menempati rumah yang sebelumnya ditempati almarhum bersama istri (jika selama perkawinan sudah memiliki tempat tinggal, tetapi jika belum ada tempat tinggal mereka tinggal bersama orang tua almarhum suami) dan memanfaatkan segala peninggalan suami untuk kepentingan kelangsungan hidup mereka dan anak-anak dari hasil perkawinan dengan alamarhum suami dan anak- anak mereka kelak serta untuk membianyai kelangsungan hidup orang tua dan keluarga almarhum suami. Akan tetapi rumah yang mereka tinggali beserta harta peninggalan almarhum suami hanya merupakan hak pakai buat mereka berdua (janda dan suami baru), mereka tidak berhak atau tidak diperbolehkan memilki ataupun menjual rumah ataupun harta peninggalan suami untuk kepentingan mereka sendiri, mereka baru diperbolehkan menjual harta peninggalan suami jika dari hasil tersebut akan dipergunakan untuk kepentingan anak-anak mereka ataupun untuk kepentingan orang tua dan saudara (kerabat) almarhum suami yang selama ini menjadi tanggungan suami.

\section{Hak dan Kewajiban Janda Cerai Mati dalam Hukum Adat Lampung Pepadun Perspektif Keadilan Gender}

a. Hak Waris Untuk Janda Cerai Mati

Ketika suami meninggal dunia ketentuan di dalam hukum adat Lampung Pepadun harta kembali dan dikelola oleh keluarga almarhum suaminya. Perempuan atau istri tidak mendapatkan bagian harta waris dari almarhum suaminya, Artinya, janda cerai mati tidak mendapatkan hak waris dari harta peninggalan almahum suami, janda tersebut hanya berhak untuk mengelola tetapi tidak berhak untuk mewarisi.

Ditinjau dari hukum Islam seorang janda cerai mati berhak menerima hak waris dari almarhum suaminya sebagaimana yang tercantum dalam Q.S.An-Nisa (4) ayat: 12. Dari ayat diatas jelaslah bahwa bagi istri itu ada dua ketentuan. Pertama, hak memperoleh bagian seperempat bagi istri itu terjadi bila tidak ada keturunan yang mewarisi, baik keturunan itu dari dirinya ataupun dari orang lain. Kedua hak memperoleh bagian seperdelapan bagi istri itu terjadi bila ada keturunan yang mewarisi. Apabila istri itu berbilang, maka mereka berbagi rata dari seperempat atau seperdelapan bagian[10]. Dalam Kompilasi Hukum Islam (KHI) pasal 180, seorang jan mendapat bagian 1/4 jika jika pewaris tidak meninggalkan anak dan mendapat bagian 1/8 jika pewaris meninggalkan anak. Ketika seorang perempuan atau janda tidak mendapatkan hak waris dari almarhum suaminya maka sistem hukum tersebut terdapat kesan pembedaan antara laki-laki dan perempuan.[11] Dimana laki-laki mendapatkan hak waris dan harta seluruhnya dikelola oleh keluarga laki-laki sedangkan perempuan tidak berhak atas harta waris.

Definisi gender adalah pembedaan peran anatara laki-laki dan perempuan, dimana pembedaan tersebut dibedakan karena berdasarkan konstruk budaya bukan berdasarkan kodrati. Dari berbagai definisi sebagaimana di atas, pengertian gender dapat disimpulkan bahwa gender adalah pembagian dan perbedaan peran antara laki-laki dan perempuan yang dikonstruksi secara social maupun cultural, gender berasal dari konsep hubungan social yang membedakan fungsi dan peran antara laki-laki dan perempuan, pembedaan fungsi dan peran antara laki-laki dan perempuan tersebut tidak ditentukan karena keduanya terdapat perbadaan bilogis atau kodrat, melainkan dibedakan menurut kedudukan, fungsi dan peran masing-masing dalam berbagai bidang kehidupan dan pembangunan. 
Konsep pembagian harta waris yang terdapat di dalam hukum adat Lampung Pepadun Marga Anak Tuha Lampung Tengah jika ditinjau dari persepektif keadilan gender, maka dapat dikatakan bahwa sistem hukum tersebut bertentangan karena tidak sejalan dengan nilai-nilai serta prinsipprinsip keadilan sebagaimana dalam Islam bahwa keadilan adalah tujuan dari hukum Islam. Selain itu, sistem pembagiannya terkesan diskriminasi bagi perempuan khususnya janda cerai mati. Dalam hukum adat Lampung Pepadun setelah suami meninggal, maka harta kembali dan dikelola oleh keluarga almarhum suaminya. Artinya, janda cerai mati tidak mendapatkan hak waris dari harta peninggalan almahum suami. Dari konsep tersebut, terlihat bahwa, ketidakadilan yang diperoleh oleh janda cerai mati karena tidak mendapatkan hak waris adalah ketidakadilan yang berbasis gender[12].

Keadilan gender menghendaki janda cerai mati wajib atas hak untuk mendapatkan bagian dari harta peninggalan suaminya baik istri itu bekerja ataupun istri tidak bekerja, karena seorang istri bagaimanapun juga tetap punya andil dalam keberhasilan suami dalam mencari harta dan mengelola harta benda yang diperoleh selama perkawinan. Pengaturan pembagian warisan dengan sistem seperti itu telah menghilangkan kesan seakan-akan si isteri tidak atau kurang berperan dalam pembinaan dan membangun kehidupan rumah tangga, terutama dalam aspek ekonominya. Konsep gender dalam Islam tidak mengajarkan diskriminasi antara lelaki dan perempuan. Di hadapan Tuhan, lelaki dan perempuan mempunyai derajat yang sama. Prinsip kesetaraan gender dalam Islam, adalah: Laki-laki dan perempuan sama-sama hamba Allah. Dalam kapasitas manusia sebagai hamba Allah, tidak ada perbedaan antara laki-laki dan perempuan, keduanya mempunyai potensi dan peluang yang sama untuk menjadi hamba yang ideal.

Keadilan gender merupakan perwujudan hak asasi manusia. Keadilan gender yang diatur di dalam konvensi internasional Convention on the Elimination All Form Of Discrimination Against Women (CEDAW) atau Konvensi Penghapusan Segala Bentuk Diskriminasi terhadap Perempuan mengandung makna prinsip "kesetaraan dan non-diskriminasi" Pertama, prinsip persamaan menuju persamaan substantif yakni memandang persamaan hak lelaki dan perempuan; Kedua, prinsip non diskriminasi terutama diskriminasi berdasarkan jenis kelamin dalam pemenuhan kebebasan-kebebasan dasar dan hak asasi manusia[11]. Rumusan tentang pembagian waris dalam hukm adat Lampung Pepadun Marga Anak Tuha jelas tidak sesuai dengan ketentuan Pasal 1 Konvensi CEDAW tentang prinsip don-diskriminasi dan persamaan.[13]

Pasal 1 menjelaskan bahwa "diskriminasi terhadap perempuan" berarti setiap pembedaan, pengucilan atau pembatasan yang dibuat atas dasar jenis kelamin, yang mempunyai pengaruh atau tujuan untuk mengurangi atau menghapuskan pengakuan, penikmatan atau penggunaan hak-hak azasi manusia dan kebebasan-kebebasan pokok di bidang politik, ekonomi, sosial, budaya, sipil atau apapun lainnya oleh kaum perempuan, terlepas dari status perkawinan mereka, atas dasar persamaan antara laki-laki dan perempuan”.

Hal inilah yang ditekankan dalam Konvensi CEDAW yaitu prinsip persamaan dan keadilan merupakan sebuah keharusan. Keharusan karena prinsip keadilan serta kesetaraan antara laki-laki dan perempuan merupakan sebuah perwujudan HAM yang dimiliki oleh semua umat, khususnya kaum perempuan. Kenapa konsep HAM itu sesuatu yang sangat penting dalam kenegaraan Indonesia, karena Indonesia telah memploklamirkan sebagai konsep negara hukum. Ciri dari negara hukum diantaranya adalah adanya jaminan terhadap perlindungan HAM serta menjunjung tinggi prinsip persamaan dan keadilan[1].

Prinsip persamaan dan keadilan khuusnya dalam hukum "equality before the Law" ini 
terkandung di dalam UUD 45 Pasal 28B ayat (1) dan (2) serta Pasal 28D ayat (1) yang berbunyi: "Setiap orang berhak atas pengakuan, jaminan, perlindungan, dan kepastian hukum yang adil serta perlakuan yang sama dihadapan hukum". Hal ini tentu sejalan dengan asas-asas negara hukum yang meliputi 5 (lima) hal, salah satu diantaranya adalah prinsip persamaan dihadapan hukum (equality before the Law) prinsip ini dalam negara hukum bermakna bahwa pemerintah tidak boleh mengistimewakan orang atau kelompok orang tertentu, atau memdiskriminasikan orang atau kelompok orang tertentu.

Di dalam prinsip ini, terkandung (a) adanya jaminan persamaan bagi semua orang di hadapan hukum dan pemerintahan, dan (b) tersedianya mekanisme untuk menuntut perlakuan yang sama bagi semua warga negara. Dengan demikian hukum atau perundang-undangan harus memberi perlindungan dan kepastian hukum yang adil khususnya terhadap perempuan.

b. Hak Hadonah atau Memelihara Anak.

Dari penelitian banyak ditemukan janda cerai mati yang melakukan pernikahan dengan lakilaki yang bukan berasal dari kerabat almarhum suami dan tidak melakukan upacara adat dan syaratsyarat adat yang telah ditentukan, karena mengingat untuk melakukan upacara adat tersebut cukup berat. Karena biaya yang dibutuhkan untuk acara adat ini cukup besar, syarat yang harus dipenuhi dalam acara adat yaitu: (1) Menyembelih seekor kerbau. Tapi untuk masa sekarang jika dirasa menyembelih seekor kerbau itu dianggap berat maka iijinkan untuk menyembelih seekor kambing. (b) Membayar uang sejumlah Rp.2.400.000,00 kepada lembaga adat, dimana uang ini nantinya akan dibagikan keseluruh lembaga adat di setiap kampung yang ada di Marga anak Tuha sebagai pemberitahuan bahwa telah dilaksanakan pengangkatan anak sebagai ganti anak yang telah meninggal oleh salah seorang warga. (c) Membianyai seluruh biaaya yang akan dikeluarkan untuk biaya prosesi adat. (d) Menyediakan biaya untuk konsumsi yang nantinya akan dinikmati oleh seluruh warga kampung dimana janda tersebut tinggal.

Jika syarat dan upacara adat tersebut tidak dilaksanakan maka secara adat janda tersebut dianggap telah mati, ketika janda dianggap mati, maka anak-anak hasil perkawinan dengan almarhum suaminya menjadi milik keluarga almarhum suaminya. Ketentuan tersebut tentu memberikan rasa ketidak-keadilan terhadap janda tersebut. Ketidak-adilan karena si janda dianggap mati, padahal faktanya janda tidak mati (meninggal), selain itu si janda juga dilarang membawa dan mengasuh anak-anak hasil perkawinan dengan almarhum suaminya.

Dari uraian sebagaimana di atas yang terkandung di dalam hukum adat Lampung Pepadun Marga Anak Tuha tentang hak hadonah bagi janda yang menikah dengan laki-laki diluar kerabat almarhum suaminya dengan cara tidak melakukan upacara adat terlebih dahulu, maka dapat dikatakan ketentuan tersebut bertentangan dengan prinsip-keadilan gender. Hukum Islam menghendaki nilai-nilai keadilan, kesetaraan di depan hukum, persamaan derajat antara laki-laki dan kaum perempuan. Keadilan dan kesetaraan gender berlandaskan pada prinsip-prinsip yang memposisikan laki-laki dan perempuan sama sebagai hamba Tuhan. Sebagaimana Firman Allah dalam surat an-Nahl; [16]: 97, al-A'raf; [7]: 172, dan surat al-A'raf; [7]: 22. Ayat ini mengisyaratkan konsep kesetaraan dan keadilan gender serta meberikan ketegasan bahwa prestasi individual baik dalam bidang spiritual maupun urusan karir propesonal, tidak mesti dimonopoli oleh salah satu jenis kelamin saja. Laki-laki dan perempuan memperoleh kesempatan yang sama untuk memperoleh prestasi yang optimal.

c. Kewajiban Menjalankan Iddah 
Dalam menjalankan kewajibannya terkait dengan masa iddah, janda cerai mati pada hukum adat lampung pepadun adalah bahwa masa iddahnya sesuai dengan hukum islam yaitu emapat bulan sepuluh hari (4 bulan 10 hari). Akan tetapi pada dasarnya, jika ditinjau dari sudut pandang konsep kesetaraan gender maka akan bertentangan. Bertantangan dengan keadilan gender disini adalah kewajiban menjalankan Iddah hanya wajib untuk perempuan semata, namun kewajiban ini tidak berlaku untuk laki-laki (suami). Hal ini terbukti bahwa konsep yang terkandung dalam prinsip persamaan kesetaraan, yaitu memperlakukan perempuan sama dengan laki-laki.

Tujuan utama yang ingin dicapai adalah "perlakuan yang sama", bukan persamaan hasil. Karena perempuan dan laki-laki dianggap sama, legislasi yang memperlakukan perempuan berbeda dianggap melanggar prinsip kesetaraan. Dengan demikian, hukum harus netral gender dan aturan harus didasarkan pada "satu standar". Pada intinya prinsip kesetaraan menurut Convention on the Elimination All Form Of Discrimination Against Women (CEDAW) adalah menghasilkan keluaran untuk memastikan persamaan kesempatan (hukum, kebijakan, program), kesetaraan dalam akses, dan kesetaraan dalam memperoleh manfaat nyata/riil. Maka, hendaklah keluarga (mertua janda cerai mati) tidak saling berbuat zalim kepada janda yang ditinggal mati suaminya. Karena hal ini terdapat larangan sebagaimana yang tertulis dalam al-Qur' an surat al-Baqarah [2]: 279.

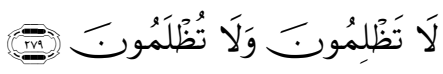

"Kamu tidak Menganiaya dan tidak (pula) dianiaya".

Apakah tidak zalim namanya, jika seorang perempuan (mantan isteri) diaharuskan menunggu, tidak boleh menerima, lamaran laki-laki lain, sementara, keluarga mantan suaminya (mertua) seenaknya meminta untuk tidak menikah dengan orang lain selain dari keluarga suami(mantan)nya. Selain itu juga terdapat nas yang memerintahkan kepada laki-laki (suami/keluarga) memperlakukan isterinya dengan baik ma'asyarah bi al-ma'ruf Dengan memperhatikan hal-hal tersebut, maka masalah iddah harus dipahami dalam perspektif kolektif, yakni mengikat secara bersama lai-laki dan perempuan sebagai masalah bersama. Jadi, mengenai masalah iddah yang diterapkan oleh masyarakat adat pepadun jika ditinjau dari perspektif gender sangat bertentangan. Hal tersebut terkesan dibebankan kepada seorang janda (cerai mati) dan hanya mengikat atau dibebankan kepadanya saja. tentunya jika ditinjau dari sudut pandang konsep CEDAW tidaklah demikian. karena ini yang menajadi titik permasalahan sebagai bentuk dari sebuah diskriminasi dalam konsep kesetaraan tersebut. Selain itu, dalam masa iddah pada hukum adat lampung pepadun, seorang janda (cerai mati) juga tidak diperkenankan untuk berkunjung kekediaman orang tua kandungnya, jika dirasionalkan secara logika, hukum adat tersebut dapat digolongkan kedalam bentuk diskriminasi[12].

\section{d. Kewajiban Menjalankan Upacara Adat}

Jika janda dan calon suami dari luar keluarga mantan suaminya itu tetap memaksa untuk tetap melaksanakan perkawinan, dengan tidak melakukan upacara adat sebagaimana yang telah ditentukan sebagaimana yang tertulis di dalam hukum adat maka ada konsekuwensi yang akan ditanggung oleh janda cerai mati dan berimplikasi terhadap hak-hak janda tersebut. Padahal seorang istri yang ditinggal mati oleh suaminya sangat manusiawi apabila ia berkeinginan untuk membangun sebuah rumah tangga kembali (menikah) tentunya setelah melewati masa iddah tanpa harus di bebani dengan ketentuan-ketentuan yang memberatkan si janda dan calon suami (dari luar keluarga mantan suaminya). 
Diskriminasi dan ketidakadilan yang dialami oleh kaum perempuan masyarakat adat Lampung Pepadun khususnya Marga Anak Tuha sebagaimana paparan di atas, jika ditinjau dari perpspektif Konvensi Internasioanal yakni CEDAW atau Konvensi Penghapusan Segala Bentuk Diskriminasi terhadap Perempuan, maka dapat dikatakan bahwa praktik-praktik hukum adat tersebut di atas sangat bertentangan dan berlawanan dengan asas dan prinsip yang terkandung di dalam ketentuan CEDAW tersebut. Ketidakadilan yang di alami oleh kaum perempuan masyarakat adat Lampung Pepadun Marga Anak Tuha terlihat jelas pada pembedaan antara perempuan dan kaum laki-laki di hadapan hukum adat. Pembedaan tersebut khususnya terletak kepada hak keadilan dalam perolehan harta waris dan praktik-praktik lainnya. Dalam praktiknya kaum perempuan banyak mengalami diskriminasi dan ketidakadilan.

Oleh karena itu, rumusan hukum adat Lampung Pepadun Marga Anak Tuha, serta bentuk praktik-praktiknya yang cenderung bisa mendiskriminasikan terhadap hak-hak kaum perempuan masyarakat adat Lampung Pepadun sebagaimana di atas, jelas tidak sesuai dengan ketentuan Pasal 15 Konvensi CEDAW yang menyatakan bahwa: "Negara-negara wajib memberikan kepada perempuan persamaan hak dengan laki-laki dimuka hukum". Hukum adat Lampung Pepadun Marga Anak Tuha, menyatakan bahwa kaum perempuan tidak berhak mendapatkan hak waris, yang berhak mendapatkan hak waris adalah anak laki-laki. Hal ini terlihat pembedaan antara laki-laki dan kaum perempuan di hadapan hukum adat, ini tentu jika ditinjau dari perspektif CEDAW kaum perempuan mengalami ketidaksetaraan antara laki-laki khususnya dalam konteks hak waris. Hal tersebut juga bertentangan dengan prinsip Konvensi CEDAW tentang prinsip Non-Disriminasi yang tertuang dalam Pasal 1 CEDAW.

Ketidakadilan lain sebagaimana di atas, bahwa kaum perempuan jika menikah dengan pilihannya sendiri yang mana calon suami di ambil dari luar keluarga almarhum suaminya, dengan tetap tidak melakukan upacara adat/ritual adat yang telah di atur di dalam hukum adat, maka akan ada konsekuwensi yang dapat diterima (janda) tersebut. Jika syarat adat tersebut tidak dilaksanakan maka secara adat janda tersebut dianggap telah mati. Hal ini tentu saja sangat berpengaruh bagi janda cerai mati yang ingin menikah kembali karena berkaitan erat dengan hak-hak yang seharusnya diterima oleh sijanda seperti hak waris, hak pemeliharan anak dan hak-hak yang lainnya. Dalam perspektif Konvensi CEDAW ketentuan tersebut juga bertentangan sebagaimana Pasal 16 Poin (a) yang menyatakan bahwa "hak yang sama untuk melakukan perkawinan" dan pont (b) yang menyatakan bahwa: "Hak yang sama untuk bebas memilih suami/pasangan dan untuk memasuki jenjang perkawinan hanya dengan persetujuan yang bebas dan sepenuhnya”.

Ketidak adilan yang dialami oleh kaum perempuan masyarakat adat lampung Pepadun Marga Anak Tuha sebagaimana di atas, selain bertentangan dengan CEDAW, juga bertentangan dengan prinsip "equality before the Law" yaitu prinsip "persamaan di hadapan hukum" prinsip ini terkandung di dalam UUD 45 Pasal 28B ayat (1) dan (2) serta Pasal 28D ayat (1) yang berbunyi: "Setiap orang berhak atas pengakuan, jaminan, perlindungan, dan kepastian hukum yang adil serta perlakuan yang sama dihadapan hukum". Hal ini tentu sejalan dengan asas-asas negara hukum yang meliputi 5 (lima) hal, salah satu diantaranya adalah prinsip persamaan dihadapan hukum (equality before the Law) prinsip ini dalam negara hukum bermakna bahwa pemerintah tidak boleh mengistimewakan orang atau kelompok orang tertentu, atau memdiskriminasikan orang atau kelompok orang tertentu. 


\section{Kesimpulan}

Ditinjau dari perspektif keadilan gender maka ketentuan hukum tentang hak janda cerai mati dalam hukum adat Lampung Pepadun Marga Anak Tuha Lampung Tengah bertentangan serta tidak sejalan dengan prinsip-prinsip keadilan dan kesetaraan gender. Pembedaan perolehan hak antara laki-laki dan perempuan dalam hukum adat Lampung Pepadun tersebut adalah bentuk ketidakadilan dan diskriminasi yang berbasis gender. Hal tersebut bertentangan dengan prinsip Konvensi CEDAW Pasal 1 tentang prinsip Non-Disriminasi. Ketidakdilan tersebut juga bertentangan dengan prinsip "equality before the Law" yaitu prinsip "persamaan di hadapan hukum" prinsip ini terkandung di dalam UUD 45 Pasal 28B ayat (1) dan (2) serta Pasal 28D ayat (1). Dalam konteks kewajiban, janda cerai mati juga mengalami intimidasi, diskriminasi dan ketidak-adilan. Janda cerai mati dalam hukum adat Lampung Pepadun jika ingin menikah diharuskan menikah dengan saudara (kerabat) dari pihak almarhum suami (perkawinan Leviraat /Nyemalang). Dalam perspektif Konvensi CEDAW ketentuan tersebut bertentangan sebagaimana Pasal 16 Poin (b) yang menyatakan bahwa "Hak yang sama untuk memilih suami secara bebas dan untuk memasuki jenjang perkawinan hanya dengan persetujuan yang bebas dan sepenuhnya”.

Hasil dari penelitian ini harapan tim penelitim seyogyanya bias menjadi bahan pertimbangan dan evaluasi dalam mengambil kebijakan bagi para tokoh adat Lampung Pepadun dalam menyelesaikan persoalan tentang hak dan kewajiban janda cerai mati dengan tetap mengedepankan nilai-nilai keadilan dan kesetaraan gender. Selain itu, dalam upaya dalam menegakkan keadilan dan kesetaraan gender perempuan masyarakat Adat Lampung Pepadun Marga Anak Tuha diperlukan sosialiasai pendidikan berbasis gender dan hak asasi manusia (HAM). Sosialisasi pendidikan dan pemahaman ini perlu dukungan masyarakat dan tokoh adat Lampung Pepadun setempat.

\section{Daftar Pustaka}

[1] D. Ferricha, Sosiologi hukum \& gender: interaksi perempuan dalam dinamika norma dan sosio-ekonomi, Ed. 1., cet. 1. Malang: Bayumedia Pub, 2010.

[2] Z. Subhan, Tafsir Kebencian: Studi Kasusu Gender dalam Tafsir Qur'an. Yogyakarta: LKiS, 1999.

[3] M. Fakih, Analisis gender dan transformasi sosial. Yogyakarta: Insist Press, 2008.

[4] redaksi, "Zulkifli Hasan Pimpin Forum Lampung Perantauan," Lnews.co, 19-Nov-2016. [Online]. Available: https://lnews.co/zulkifli-hasan-pimpin-forum-lampung-perantauan/. [Accessed: 31-Dec-2018].

[5] S. Sutan Kanjeng, "Penyimbang sebagai penyimbang adat Marga Anak Tuha," 02-Mar2016.

[6] A. Aziz, "ISLAM DAN KEKERASAN DALAM RUMAH TANGGA," Jurnal Kordinat, vol. 16, no. 1, pp. 177-196, Apr. 2017.

[7] marsudah marsudah, "janda cerai mati," 2016.

[8] S. Sami'a, "janda cerai mati," Oktober-2016.

[9] S. Syamsinar, "janda cerai mati," Oktober-2016.

[10] S. Sabiq, Fiqh Sunnah. Bandung: Al-Maarif, 1986.

[11] S. W. Hesti Utami, Kesetaraan Gender "Langkah Menuju Demokratisasi Desa. Yogyakarta: IP. Lappera Indonesia, 2001.

[12] "Pelatihan CEDAW untuk aktivis LSM | Blog Kalyanamitra." [Online]. Available: http://www.kalyanamitra.or.id/blog/2009/07/pelatihan-cedaw-untuk-aktivis-lsm/. [Accessed: 17-Jan-2018].

[13] S. sadli, Hak Asai Perempuan Adalah Hak Asasi, Dalam Pemahaman Bentuk-Bentuk Tindak Kekerasan Terhadap Perempuan Dan Alternatif Pemecahannya. Jakarta: Pusat Kajian Wanita dan Gender, 2000. 